Ricardo Queiroz de Araujo Fernandes

Proximity-based Understanding of Conditionals 


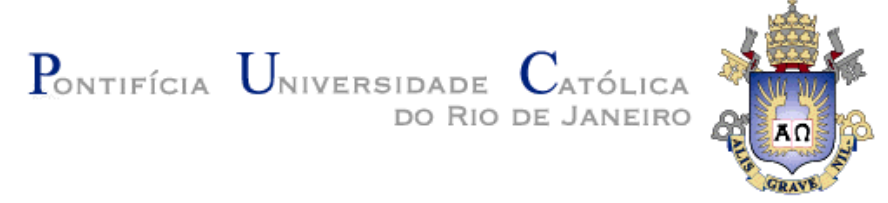

Ricardo Queiroz de Araujo Fernandes

\section{Proximity-based Understanding of Conditionals}

Thesis presented to the Programa de Pós-Graduação em Informática of the Departamento de Informática of PUC-Rio as partial fulfillment of the requirements for the degree of Doutor em Informática.

Advisor: Prof. Edward Hermann Haeusler 


\section{Ricardo Queiroz de Araujo Fernandes Proximity-based Understanding of Conditionals}

Thesis presented to the Postgraduate Program in Informatics, of the Departamento de Informática do Centro Técnico Científico da PUC-Rio, as partial fulfillment of the requirements for the degree of Doutor.

Prof. Edward Hermann Haeusler

Advisor

Department of Informatics - PUC-Rio

Prof. Luiz Carlos Pinheiro Dias Pereira Department of Philosophy — PUC-Rio

Prof. Mario Roberto Folhadela Benevides Department of Computer Science - COPPE

Prof. Ruy José Guerra Barretto de Queiroz

Department of Informatics — UFPE

Prof. Renato Fontoura de Gusmão Cerqueira Department of Informatics - PUC-Rio

Prof. Alex de Vasconcellos Garcia Department of Computer Engineering - IME

Prof. José Eugenio Leal

Coordinator of the Centro Técnico Científico da PUC-Rio 
All rights reserved.

\section{Ricardo Queiroz de Araujo Fernandes}

Ricardo Queiroz de Araujo Fernandes graduated from the Military Institute of Engineering (IME - Rio de Janeiro, Brazil) in Computer Engineering. He then worked for the Brazilian Army in corporate and operational networks. He then obtained a Master degree at the Federal University of Rio Grande do Sul (UFRGS - Porto Alegre, Brazil) in Pure Mathematics, with emphasis in discrete algebraic geometry. He then obtained a Master degree at the Military Institute of Engineering (IME - Rio de Janeiro, Brazil) in Systems and Computation, with emphasis in natural language processing. He then works for the Brazilian Army on the development of Command and Control systems.

Bibliographic data

Fernandes, Ricardo Queiroz de Araujo

Proximity-based Understanding of Conditionals / Ricardo Queiroz de Araujo Fernandes; advisor: Edward Hermann Haeusler. - 2012.

87 f: il. ; $30 \mathrm{~cm}$

Tese (doutorado) - Pontifícia Universidade Católica do Rio de Janeiro, Departamento de Informática, 2012.

Inclui bibliografia

1. Informática - Teses. 2. Condicionais. 3. Lógica. 4. Dedução natural. 5. Lógica contrafactual. 6. Lógica deôntica. I. Haeusler, Edward Hermann. II. Pontifícia Universidade Católica do Rio de Janeiro. Departamento de Informática. III. Título. 
To my wife Sabrina and my son Eduardo. 


\section{Acknowledgments}

To my mother and father, for the love they gave me. To my son, born during this work, to make me comprehend the love my parents gave me. To my wife for the gift of having a child and for sharing the life with me. To my brother and sisters and all my family.

To my advisor Professor Edward Hermann Haeusler, who offered me the opportunity of this cooperation, for the support, the everyday kindness and the incentive for the realisation of this work.

To PUC-Rio, for the VRAc sponsor, without which this work would not have been realized.

To the Brazilian Army, that gave me the opportunity of continuous studying. To my superiors Colonel Lucena, Lieutenant-Colonel Maurício and Major Alisson for the time they gave me to produce this work. To all my colleagues of the project "C2 em Combate" for the support in my absences.

To the German Academic Exchange Service (DAAD) for the Specialist Literature Programme, which provided many books used in this work.

To my colleagues of the PUC-Rio, who made the privilege of studying at PUC-Rio a real enjoyment. Also to my colleagues of PUC-Rio that helped me solving administrative problems, particularly Cecília Englander and Bruno Lopes Vieira.

To the people of the Department of Informatics for the constant help, particularly to Regina Zanon and Tereza Canuto. 


\section{Resumo}

Fernandes, Ricardo Queiroz de Araujo; Haeusler, Edward Hermann. Compreensão de condicionais a partir da proximidade. Rio de Janeiro, 2012. 87p. Tese de doutorado - Departamento de Informática, Pontifícia Universidade Católica do Rio de Janeiro.

Apresentamos uma lógica para a compreensão de condicionais a partir da proximidade (PUC-Logic) que unifica as lógicas Contrafactual e Deôntica propostas por David Lewis. Propomos também um sistema de dedução natural (PUC-ND) associado a essa nova lógica. Esse sistema de inferência é correto, completo, normalizável e decidível. A completude relativa para as lógicas V e CO é apresentada para dar ênfase à abordagem unificada sobre o trabalho de Lewis. Depois disso, apresentamos uma perspectiva construtivista para mostrar que a abstração contrafactual de Lewis não exige a regra do absurdo clássico.

\section{Palavras-chave}

Condicionais; Lógica; Dedução natural; Lógica contrafactual; Lógica deôntica 


\section{Abstract}

Fernandes, Ricardo Queiroz de Araujo; Haeusler, Edward Hermann (Advisor). Proximity-based Understanding of Conditionals. Rio de Janeiro, 2012. 87p. DSc Thesis - Depatamento de Informática, Pontifícia Universidade Católica do Rio de Janeiro.

We present a logic for Proximity-based Understanding of Conditionals (PUC-Logic) that unifies the Counterfactual and Deontic logics proposed by David Lewis. We also propose a natural deduction system (PUC-ND) associated to this new logic. This inference system is proven to be sound, complete, normalizing and decidable. The relative completeness for the $\boldsymbol{V}$ and $\boldsymbol{C} \boldsymbol{O}$ logics is shown to emphasize the unified approach over the work of Lewis. We, then, present a constructive approach to counterfactuals to show that the Lewis counterfactual abstraction does not require the classical absurd rule.

\section{Keywords}

Conditionals; Logic; Natural deduction; Counterfactual logic; Deontic $\operatorname{logic}$ 


\section{Contents}

I Counterfactuals $\quad 11$

$\begin{array}{lll}\text { I.1 Lewis analysis } & 12\end{array}$

II Proximity-based Understanding of Conditionals $\quad 16$

II.1 PUC Soundness and Completeness 26

II.2 Normalization, Decidability, Complexity 46

II.3 Counterfactual logics $\quad 51$

$\begin{array}{lll}\text { II.4 Deontic logics } & 56\end{array}$

$\begin{array}{ll}\text { III intuitionistic PUC-Logic } & 67\end{array}$

$\begin{array}{ll}\text { III.1 iPUC Soundness and Completeness } & 68\end{array}$

$\begin{array}{ll}\text { III.2 Constructive Counterfactuals } & 78\end{array}$

IV Related Works $\quad 84$

$\begin{array}{llrl}\text { V Conclusions } & 85\end{array}$ 


\section{List of Figures}

$\begin{array}{lll}\text { I.1 A system of spheres around some world } i & 13\end{array}$

II.1 Natural Deduction System for PUC-Logic (PUC-ND) 22

III.1 The additional rules of $\mathrm{iPUC}^{V}$-ND 81 
Não fez Deus o céu em xadrez de estrelas, como os pregadores fazem o sermão em xadrez de palavras.

Padre Antonio Vieira, Sermão da Sexagésima. 